\title{
On-line Microwave-Assisted Sample Decomposition for Lead Determination in Fish Slurry Samples by Electrothermal Atomic
}

\author{
Absorption Spectrometry \\ Marco A.Z. Arruda ${ }^{{ }^{+}}$, Anne H. Fostier and Francisco J. Krug \\ Centro de Energia Nuclear na Agricultura, Universidade de S. Paulo, C.P. 96, \\ 13418-260 Piracicaba - SP, Brazil
}

Received: January 19, 1996; September 10, 1996

\begin{abstract}
Um procedimento FIA envolvendo decomposição em linha auxiliada por microondas foi proposto para a determinação de chumbo em peixes por espectrometria de absorção atômica com atomização eletrotérmica. Um volume de $300 \mu \mathrm{L}$ da amostra em forma de suspensão foi injetado simultaneamente com $400 \mu \mathrm{L}$ de ácido nítrico $\left(6 \mathrm{~mol} \mathrm{~L}^{-1}\right)$, e a mistura foi dirigida para um reator tubular posicionado dentro do forno de microondas. A amostra processada foi coletada em uma cubeta do amostrador de um espectrômetro de absorção atômica com forno de grafite. A curva analítica mostrou-se linear entre 2,5 e $25,0 \mu \mathrm{g} \mathrm{L}{ }^{-1} \mathrm{~Pb}$ e o limite de detecção foi determinado como $0,72 \mu \mathrm{g} \mathrm{L}^{-1}$. A precisão, expressa em desvio padrão relativo, foi de $10,5 \%$ (n $=20)$ para repetibilidade e de $14,3 \%(n=10)$ para reprodutibilidade. A exatidão do método foi confirmada empregando-se um material de referência e comparando-se os resultados obtidos com um procedimento envolvendo decomposição nítrico-perclórica.
\end{abstract}

An on-line microwave-assisted decomposition procedure for the determination of lead in fish is proposed. $300 \mu \mathrm{L}$ slurry and $400 \mu \mathrm{L}$ of a $6 \mathrm{~mol} \mathrm{~L}^{-1} \mathrm{HNO}_{3}$ solution were simultaneously injected, and the mixture was positioned inside a microwave oven. The decomposed sample inside the flushing solution was collected in the autosampler cup of a graphite furnace. The proposed procedure covered the 2.5 to $25 \mu \mathrm{g} \mathrm{L}^{-1} \mathrm{~Pb}$ range and presented a detection limit of $0.72 \mu \mathrm{g}$ $\mathrm{L}^{-1} \mathrm{~Pb}$. Precision expressed as RSD, was $10.5 \%(\mathrm{n}=20)$ for repeatability and $14.3 \%(\mathrm{n}=10)$ for reproducibility. Accuracy was assessed using standard reference material, and also by comparing the results to a nitric-perchloric decomposition procedure.

Keywords: on-line microwave decomposition, fish analysis, lead determination, electrothermal atomic absorption spectrometry

\section{Introduction}

The content of lead in the environment and food is of great concern because it is recognized as a cumulative poison in animals and humans. Lead intake by humans has been estimated at 200-300 $\mu \mathrm{g}$ per day, varying as a function of the degree of contamination. Usually food is responsible for up to $70 \%$ of daily lead intake ${ }^{1}$.

The toxicity of lead in humans and animals is usually chronic because it is excreted more slowly than it is absorbed, resulting in an accumulation in various tissues. Symptoms of lead poisoning include irritability, anorexia,

\footnotetext{
${ }^{+}$Present address: Departamento de Química Analítica, Universidade de Campinas, C.P. 6154, 13083-970 Campinas - S. Paulo, Brazil
}

malaise, and headaches. Depending on the degree of intoxication, constipation and attacks of abdominal pain (lead colic) may be observed. Children are more susceptible to lead poisoning because they absorb a higher percentage of lead through the gastrointestinal tract, have more hand-to-mouth activity, and have developing nervous systems that are more sensitive to lead ${ }^{2-4}$.

In monitoring and health risk evaluation programs, the number of environmental and biological samples is often high, and the sample preparation steps become a limiting factor for analysis, mainly in terms of the time required and problems of contamination. Slurry sampling is a good 
choice for circumventing these problems, and this technique has been successfully used for direct introduction of samples in atomic spectrometry ${ }^{5-7}$ and introduced directly into the atomization system by means of flow injection systems ${ }^{8,9}$. In some instances, however, the elements to be determined are not easily atomized from solid particles because of the complexity of the matrix, and a pre-treatment step is required. An alternative for circumventing this problem is the use of a microwave technique as a heat source for sample decomposition, thus reducing the time required for solubilization and losses of volatile elements.

Coupling continuous flow systems with microwave digestors has been carried out in combination with flame atomic absorption ${ }^{10-12}$ or inductively coupled plasma atomic emission spectrometry ${ }^{13,14}$. However, few applica- tions with electrothermal atomic absorption spectrometry have been reported ${ }^{15,16}$. The state of the art and the features of several slurry techniques proposed for lead determination $^{17,29}$ are summarized in Table 1.

The present paper describes a simple and fast procedure which exploits an on-line decomposition of slurry samples coupled to a flow injection system. The effectiveness of the method was evaluated by determining lead in fish samples.

\section{Experimental}

\section{Apparatus}

A Perkin-Elmer model $4100 \mathrm{ZL}$ atomic absorption spectrometer equipped with a longitudinal Zeeman background corrector and a pyrolytically coated transversely heated graphite atomizer with an integrated L'vov platform

Table 1. Features of slurry sampling techniques for the determination of lead in food samples by atomic spectrometric techniques.

\begin{tabular}{|c|c|c|c|c|c|c|}
\hline \multirow[t]{2}{*}{ Detection } & \multirow[t]{2}{*}{ Application } & \multirow{2}{*}{$\begin{array}{c}\mathrm{RSD} \\
(\%)\end{array}$} & \multicolumn{3}{|c|}{ Suspensions } & \multirow[t]{2}{*}{ Ref. } \\
\hline & & & Stabilizer & Particle Size & Concentration & \\
\hline HGAAS & Anchovies & 4.2 & Triton X-100 & - & $2-10 \%(\mathrm{~m} / \mathrm{v})$ & 17 \\
\hline ETAAS & Biscuit & 27.3 & Ethanol- $\mathrm{H}_{2} \mathrm{O}_{2}$ & - & - & 18 \\
\hline ETAAS & Bovine liver & 54.0 & Antifoam B emulsion & $<50 \mu \mathrm{m}$ & $10 \%(\mathrm{~m} / \mathrm{v})$ & 19 \\
\hline ETA-LE-AFS & Bovine liver & - & Triton X-100 & - & $0.2 \%(\mathrm{~m} / \mathrm{v})$ & 20 \\
\hline ETAAS & Bread cereals & 44.4 & Ethanol- $\mathrm{H}_{2} \mathrm{O}_{2}$ & - & - & 18 \\
\hline ETAAS & Brussel sporuts & - & Viscalex HV-30 & - & - & 21 \\
\hline ETAAS & Fish & 13.6 & Antifoam B emulsion & $<50 \mu \mathrm{m}$ & $10 \%(\mathrm{~m} / \mathrm{v})$ & 19 \\
\hline ETAAS & Fish & 13.0 & Glycerine-methanol- $\mathrm{HNO}_{3}$ & - & $15-300 \mu \mathrm{g}$ in $5 \mu \mathrm{L}$ of slurry & 22 \\
\hline HGAAS & Hay & 4.3 & Triton X-100 & $<25 \mu \mathrm{m}$ & - & 23 \\
\hline HGAAS & H-9 whole total diet & 10.0 & Triton X-100 & $<25 \mu \mathrm{m}$ & $2-10 \%(\mathrm{~m} / \mathrm{v})$ & 24 \\
\hline ETAAS & Kale & 10.0 & Antifoam B emulsion & $<50 \mu \mathrm{m}$ & $10 \%(\mathrm{~m} / \mathrm{v})$ & 19 \\
\hline HGAAS & Lettuce & 13.8 & Triton $\mathrm{X}-100$ & $<25 \mu \mathrm{m}$ & - & 23 \\
\hline HGAAS & Lettuce & 5.6 & Triton X-100 & - & $2-10 \%(\mathrm{~m} / \mathrm{v})$ & 17 \\
\hline HGAAS & Lettuce & 5.5 & Triton X-100 & $<25 \mu \mathrm{m}$ & $2-10 \%(\mathrm{~m} / \mathrm{v})$ & 24 \\
\hline ETAAS & Milk powder & - & - & - & - & 25 \\
\hline HGAAS & Mussels & 7.9 & Triton X-100 & $<25 \mu \mathrm{m}$ & - & 23 \\
\hline ETA-LE-AFS & Non-fat milk powder & - & Triton X-100 & - & $0.2 \%(\mathrm{~m} / \mathrm{v})$ & 20 \\
\hline ETAAS & Paprika & $2.7-6.7$ & Ethanol- $\mathrm{H}_{2} \mathrm{O}_{2}$ & $<30 \mu \mathrm{m}$ & $0.05-0.4 \%(\mathrm{~m} / \mathrm{v})$ & 26 \\
\hline ICP-AES & Pepper & $1.6-3.8$ & Triton X-100 & $5-3.5 \mu \mathrm{m}$ & $0.5 \%(\mathrm{~m} / \mathrm{v})$ & 27 \\
\hline ICP-MS & Rice flour & - & & $<3 \mu \mathrm{m}$ & & 28 \\
\hline HGAAS & Sardines & 7.1 & Triton X-100 & - & $2-10 \%(\mathrm{~m} / \mathrm{v})$ & 17 \\
\hline ETAAS & Spinach & 3.0 & Viscalex HV30 & $1-50 \mu \mathrm{m}$ & up to $10 \%(\mathrm{~m} / \mathrm{v})$ & 29 \\
\hline ETAAS & Spinach & 10.6 & Glycerine-methanol- $\mathrm{HNO}_{3}$ & - & $15-300 \mu \mathrm{g}$ in $5 \mu \mathrm{L}$ of slurry & 22 \\
\hline ETAAS & Wheat flour & 28.6 & Ethanol- $\mathrm{H}_{2} \mathrm{O}_{2}$ & - & - & 18 \\
\hline
\end{tabular}

HGAAS: hydride generation atomic absorption spectrometry; ETAAS: electrothermal atomic absorption spectrometry; ETA-LE-AFS: electrothermal atomizer-laser excited-atomic fluorescence spectrometry; ICP-AES: inductively coupled plasma atomic emission spectrometry; ICP-MS: inductively coupled plasma mass spectrometry. 
(Perkin-Elmer part n B050-4033) and an AS-71 furnace autosampler were used. The wavelength was set at $283.3 \mathrm{~nm}$ using a Perkin-Elmer EDL II system as the radiation source with a $0.7 \mathrm{~nm}$ spectral bandwidth. The integrated absorbance was used, and the results were recorded on an Epson LQ-870 printer. The furnace program is shown in Table 2. A mixture of $90 \% \mathrm{Ar}$ and $10 \% \mathrm{H}_{2} \mathrm{v} / \mathrm{v}$ was employed as the purge gas.

The flow system comprised an Ismatec mp13GJ4 peristaltic pump with Tygon pumping tubes, a laboratory-made three-piece injector commutator ${ }^{30}$ with built-in T-shaped connectors, poly(tetrafluoroethylene) (PTFE) transmission lines of $0.8 \mathrm{~mm}$ i.d., and a model CEM MDS-81D microwave oven, equipped with a magnetron of $2450 \mathrm{MHz}$ with a nominal maximum power of $700 \mathrm{~W}$. The digestion coil was introduced into the microwave oven through the pressure and temperature sensor holes. A Hewlett-Packard 8451A diode-array spectrophotometer equipped with a conventional quartz cell was used to verify the stability of the slurries.

\section{Reagents}

All reagents were of analytical grade, and distilled/deionized water was used. Nitric acid was distilled in a quartz sub-boiling still (Kürner). The $1000 \mathrm{mg} \mathrm{L}^{-1} \mathrm{~Pb}$ stock solution was prepared from lead nitrate (Johnson \& Mattey, Co.) in $0.1 \% \mathrm{v} / \mathrm{v} \mathrm{HNO}_{3}$. The reference solutions containing 2.5-25 $\mu \mathrm{g} \mathrm{L}^{-1} \mathrm{~Pb}$ were prepared by serial dilutions of the stock solution with $2.4 \mathrm{~mol} \mathrm{~L}^{-1} \mathrm{HNO}_{3}$. Mix of $0.003 \mathrm{mg}$ of $\mathrm{Mg}\left(\mathrm{NO}_{3}\right)_{2}$ plus $0.05 \mathrm{mg}$ of $\mathrm{NH}_{4} \mathrm{H}_{2} \mathrm{PO}_{4}$ was used as a chemical modifier and Triton X-100 scintillation grade (Amersham/Searle) was employed to stabilize the slurry samples.

The effect of concomitants was evaluated using a lead reference solution containing $10 \mu \mathrm{g} \mathrm{L}^{-1}$ in $2.4 \mathrm{~mol} \mathrm{~L}^{-1}$ $\mathrm{HNO}_{3}$ without the concomitants, or in the presence of $2 \mathrm{mg} \mathrm{L}^{-1} \mathrm{Fe}, 2 \mathrm{mg} \mathrm{L}^{-1} \mathrm{Zn}, 300 \mathrm{mg} \mathrm{L}^{-1} \mathrm{Cl}^{-}, 400 \mathrm{mg} \mathrm{L}^{-1} \mathrm{~K}, 300$ $\mathrm{mg} \mathrm{L}^{-1} \mathrm{Na}$, or $90 \mu \mathrm{g} \mathrm{L}^{-1} \mathrm{Cu}$.

\section{Sample preparation}

The fish samples, collected in the Amaparí river (Amapá, Brazil), were ground with a mixer in order to make a slurry. After being frozen for five days, the resulting slurry was lyophilized by freeze-drying at $6 \mathrm{~Pa}$ for 48 $\mathrm{h}$ up to a constant weight. The resulting lyophilized samples were sieved through a standard nylon sieve in order to obtain a particle size $\leq 200 \mu \mathrm{m}$. Then an accurately weighed amount of about $250 \mathrm{mg}$ was mixed with $3 \mathrm{~mL}$ of $2.4 \mathrm{~mol} \mathrm{~L}^{-1} \mathrm{HNO}_{3}$ and $1 \mathrm{~mL}$ of $0.25 \% \mathrm{v} / \mathrm{v}$ Triton $\mathrm{X}-100$, and the volume was completed to $5 \mathrm{~mL}$ with $2.4 \mathrm{~mol} \mathrm{~L}^{-1}$ $\mathrm{HNO}_{3}$. Agitation for $20 \mathrm{~min}$ in an ultrasonic bath was necessary to homogenize the slurry sample. Standard Reference Material MA-A-2 n 1062/TM - Fish homogenate
Table 2. The furnace program for the determination of $\mathrm{Pb}$; injected volume, $20 \mu \mathrm{l}$ of sample $+10 \mu \mathrm{L}$ modifier.

\begin{tabular}{lcccc}
\hline Step & $\begin{array}{c}\text { Temperature } \\
\left({ }^{\circ} \mathrm{C}\right)\end{array}$ & \multicolumn{2}{c}{ Time (s) } & $\begin{array}{c}\text { Gas flow rate } \\
\left(\mathrm{mL} \mathrm{min}^{-1}\right)\end{array}$ \\
\hline Dry1 & 130 & 20 & 35 & 250 \\
Dry2 & 160 & 20 & 25 & 250 \\
Pyrolysis & 850 & 10 & 20 & 250 \\
Atomization & 1500 & 0 & 5 & 0 \\
Clean & 2600 & 1 & 2 & 250 \\
\hline
\end{tabular}

Program time: $138 \mathrm{~s}$; Injection temperature: $100^{\circ} \mathrm{C}$.

(International Agency of Energy Atomic) was used to check the accuracy of the proposed procedure.

Additionally, and for the purposes of comparision, the samples also underwent nitric-perchloric digestion. Each fish sample was accurately weighed (0.4-0.5 g, dry weight) and transferred together with $10 \mathrm{~mL}$ of concentrated nitric acid, to a $75 \mathrm{~mL}$ conical flask. After complete dissolution ( $c a .2 \mathrm{~h}$ ), the flask was placed on a hot plate at $160{ }^{\circ} \mathrm{C}$ until a clear solution was obtained. Next, $2 \mathrm{~mL}$ of perchloric acid was carefully added to the flask and the temperature was increased to $210^{\circ} \mathrm{C}$. The decomposition was completed with the appearance of white fumes and approximately $0.5 \mathrm{~mL}$ solution remained. The decomposed sample was then transferred to a $10 \mathrm{~mL}$ volumetric flask, and diluted to mark with $2.4 \mathrm{~mol} \mathrm{~L}^{-1} \mathrm{HNO}_{3}$.

\section{Procedure}

The flow system for on-line fish decomposition is illustrated in Fig. 1. In the position specified, both loops, loaded with $300 \mu \mathrm{L}$ sample and $400 \mu \mathrm{L}$ digestion solutions $(6 \mathrm{~mol}$ $\mathrm{L}^{-1} \mathrm{HNO}_{3}$ ), were inserted into the air carrier streams at 2 $\mathrm{mL} \mathrm{min}^{-1}$ and driven towards the confluence point $(\mathrm{X})$; the mixed solution was then directed towards the $500 \mathrm{~cm}$ PTFE digestion coil ( $0.8 \mathrm{~mm}$ i.d.) located inside the microwave oven. The coil was wrapped around an Erlenmeyer flask

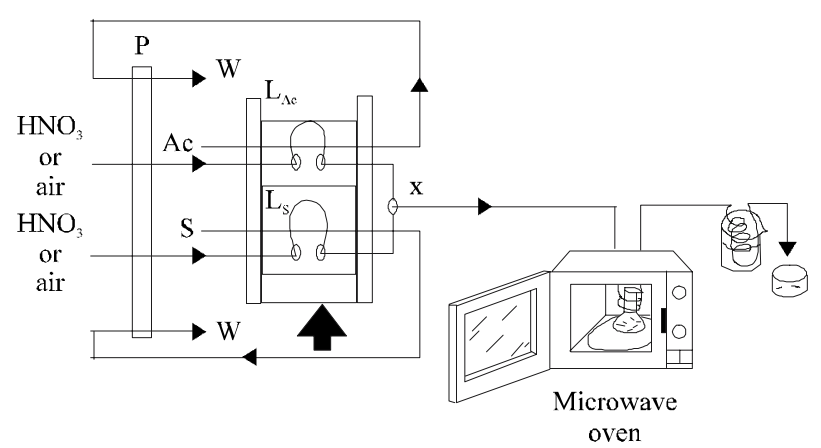

Figure 1. The FI-microwave oven-ETAAS system for the determination of lead in fish samples. $\mathrm{Ls}_{S}$ and $\mathrm{L}_{\mathrm{Ac}}$ are the sample $(300 \mu \mathrm{L})$ and nitric acid $(400 \mu \mathrm{L})$ loops, respectively, and W is waste. Air flow rate, 2 $\mathrm{mL} \min ^{-1}$. 
filled with water, which assured a volume $(150 \mathrm{~mL})$ inside the cavity sufficient to prevent damage in the magnetron. About $50 \mathrm{~s}$ after sample injection, when the entire sample plug was flowing inside the digestion coil, the peristaltic pump was stopped and the microwave program (Table 3) was started. After the microwave action, the pump was re-started and a $0.1 \% \mathrm{v} / \mathrm{v} \mathrm{HNO}_{3}$ solution was introduced via the tube of the air carrier in order to clear the residual decomposed sample and to transport the sample to the autosampler cup which was completely filled (total volume, $1 \mathrm{~mL}$ ). A $150 \mathrm{~cm}$ coil immersed in a water-filled beaker was incorporated into the flow system to allow the expansion of digestion fumes. The same procedure was followed for the blanks. After the processing of each sample, the air carrier streams were introduced into the flow manifold again in order to remove the residual washing solution.

\section{Results and Discussion}

\section{The stability of the slurries}

In order to check the stability of the slurry sample, an experiment was carried out ${ }^{31}$ using a diode-array spectrophotometer to record changes in the turbidimetry of the fish sample. Fig. 2 shows the variation in the absorbance measured at $500 \mathrm{~nm}$ for a slurry containing 250 $\mathrm{mg}$ fish sample dispersed in $4 \mathrm{~mL}$ of $2.4 \mathrm{~mol} \mathrm{~L}^{-1} \mathrm{HNO}_{3}$ plus $1 \mathrm{~mL}$ of $0.25 \% \mathrm{v} / \mathrm{v}$ Triton $\mathrm{X}-100$. The change in absorbance was monitored for 6 minutes and its variation was $20 \%$. However, when this change was measured for 5 min only

Table 3. The microwave oven program for fish sample digestion.

\begin{tabular}{lrrrrrrr}
\hline Power(W) & 350 & 0 & 350 & 0 & 350 & 0 & 350 \\
Time (s) & 120 & 20 & 120 & 20 & 120 & 20 & 120 \\
\hline
\end{tabular}

Total time: $540 \mathrm{~s}$; Digestion time: $480 \mathrm{~s}$.

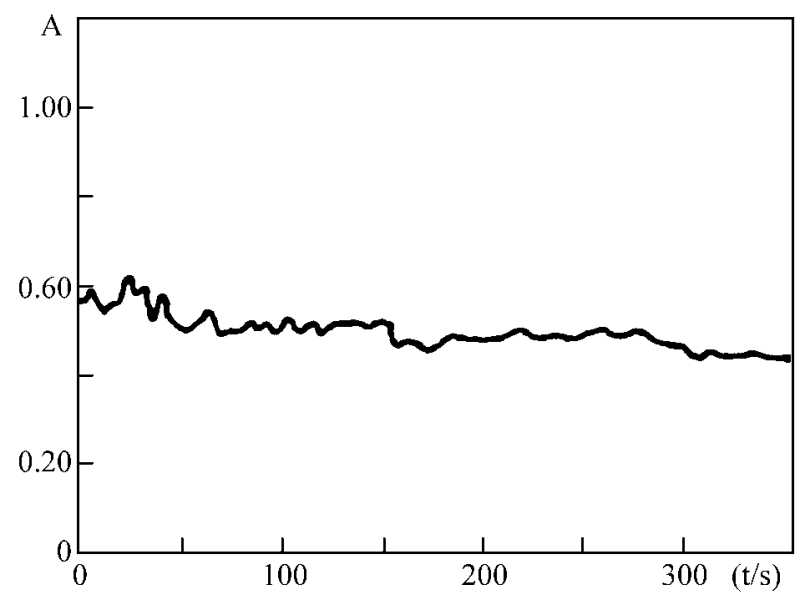

Figure 2. The temporal variation of the absorbance at $500 \mathrm{~nm}$ of 250 $\mathrm{mg}$ of fish sample dispersed in $\mathrm{HNO}_{3}(c a .4 \mathrm{~mL})$ plus $1 \mathrm{~mL} 0.25 \% \mathrm{v} / \mathrm{v}$ Triton X-100.
$13 \%$ was observed, indicating that this condition is sufficient for the sample preparation. Without a thixotropic agent, changes in absorbance of up to $50 \%$ were detected for this type of sample.

As the time necessary to fill the sample loop of the flow system was about $30 \mathrm{~s}$, the time during which the slurry remained stabilized was sufficient.

\section{Furnace heating conditions}

The furnace program (Table 2) included a hot injection procedure and two temperature ramps in order to guarantee soft and totally dry conditions of the sample, to avoid problems from matrix effects. Also, a $90 \%$ Ar plus $10 \% \mathrm{H}_{2} \mathrm{v} / \mathrm{v}$ mixture was used as the purge gas because it increases the dissociation of the lead molecular species in the gas phase and reduces matrix interferences ${ }^{32}$.

In order to optimize the furnace conditions and to avoid lead loss during pyrolysis, use of chemical modifiers is an excellent choice. So, some chemical modifiers were tested: $\mathrm{NH}_{4} \mathrm{H}_{2} \mathrm{PO}_{4}, \mathrm{Mg}\left(\mathrm{NO}_{3}\right)_{2}$, and $\mathrm{NH}_{4} \mathrm{H}_{2} \mathrm{PO}_{4}+\mathrm{Mg}\left(\mathrm{NO}_{3}\right)_{2}$. The situation without a modifier was also checked.

The experiment of the pyrolysis step was performed by maintaining the atomization temperature at $1500{ }^{\circ} \mathrm{C}$ and varying the pyrolysis temperature. In this experiment, the optimum heating conditions did not significantly differ in sensitivity, regardless of the different chemical modifiers. The loss of $10 \mu \mathrm{g} \mathrm{L}^{-1}$ lead standard solution was observed in the pyrolysis cycle at $900{ }^{\circ} \mathrm{C}$ for almost all chemical modifiers, except for the $\mathrm{NH}_{4} \mathrm{H}_{2} \mathrm{PO}_{4}+\mathrm{Mg}\left(\mathrm{NO}_{3}\right)_{2}$ mixture where analyte loss was observed only at $1100{ }^{\circ} \mathrm{C}$. However, when using a decomposed fish sample with about 10 $\mu \mathrm{g} \mathrm{L}^{-1} \mathrm{~Pb}$ the same behaviour was not observed. When the $\mathrm{NH}_{4} \mathrm{H}_{2} \mathrm{PO}_{4}+\mathrm{Mg}\left(\mathrm{NO}_{3}\right)_{2}$ modifier was used, losses of lead were observed at $900^{\circ} \mathrm{C}$. Therefore, the pyrolysis temperature chosen was $850{ }^{\circ} \mathrm{C}$.

\section{The digestion conditions for solid samples}

Because of the lack of uniformity of microwave distribution $^{33,34}$ inside the oven, the best position for the digestion coil was determined by placing 14 glass beakers in different positions (Fig. 3), each containing $50 \mathrm{~g}$ of water. The microwave power selected was $700 \mathrm{~W}$ for $8 \mathrm{~min}$. This experiment was made in quintuplicate, and the results of the weight loss were calculated by the difference between the weights of the water-filled beaker before and after microwave action, which ranged between 2.04 and $9.48 \mathrm{~g}$. The best position found for the action of the microwave based on microwave power spatial distribution is shown in Fig. 3. These positions were at 35 and $6 \mathrm{~cm}$, on the $x$ and $y$ axes, respectively.

Nitric acid was selected as the solubilizer, based on previous work ${ }^{16}$. In order to establish the required time and acid concentration for the optimization of the digestion 


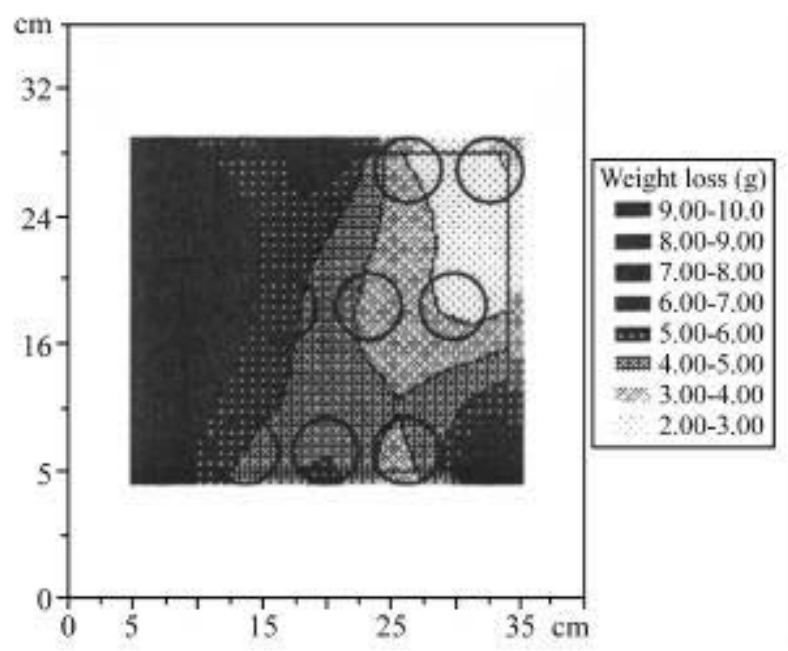

Figure 3. Influence of the position of the sample relative to the microwave magnetron on weight loss. Microwave power spatial distribution inside the oven for the influence of axes $\mathrm{x}$ and $\mathrm{y}$ (in $\mathrm{cm}$ ) on weight loss.

conditions for total recovery of lead in the analysis of solid samples, a factorial experiment was carried out. In this context, an appropriate amount of $250 \mathrm{mg}$ fish samples (Standard Reference Material MA-A-2 n 1062/TM, IAEA) was prepared as mentioned in the Sample Preparation Section, and then introduced into the above-mentioned flow system. Volumes of $300 \mu \mathrm{L}$ for samples and $400 \mu \mathrm{L}$ for the acid were injected into the flow system using a merging-zone approach $^{35}$. The sample-injected volume was selected based on the sensitivity of the method. For smaller volumes, the sensitivity was not acceptable and erratic results were obtained (RSD $>25 \%$ ). For optimization of digestion conditions, a power of $350 \mathrm{~W}$ was fixed, and the digestion time was varied between 0 and $16 \mathrm{~min}$, while the acid concentration was varied between 0 and $6 \mathrm{~mol} \mathrm{~L}^{-1}$. When microwaves were not applied, recovery was only 14.6, 23.1 and $37.7 \%$ for nitric acid concentrations of 0,3 , and $6 \mathrm{~mol}$ $\mathrm{L}^{-1}$, respectively. Fig. 4 shows the response surface related to the digestion parameters. At $350 \mathrm{~W}$, the time required to pretreat the fish samples was $8 \mathrm{~min}$, an acceptable recovery value of $113 \%$ being obtained when $6 \mathrm{~mol} \mathrm{~L}^{-1} \mathrm{HNO}_{3}$ was used. It should be pointed out that higher acid concentrations were not used to avoid eventual damage of some parts of the digestion system, as well as of the injector commutator. In the microwave oven program (Table 3), three steps without microwave action, intercalated with other steps, were necessary to maintain the sample inside the oven, due to gas formation during microwave digestion.

No memory effect was observed by digesting a blank solution after a fish sample.

\section{Analytical characteristics}

A linear range $(\mathrm{r}=0.999 ; \mathrm{n}=7)$ between 2.5 and $25.0 \mu \mathrm{g} \mathrm{L}{ }^{-1} \mathrm{~Pb}$ was obtained using the optimized flow con-

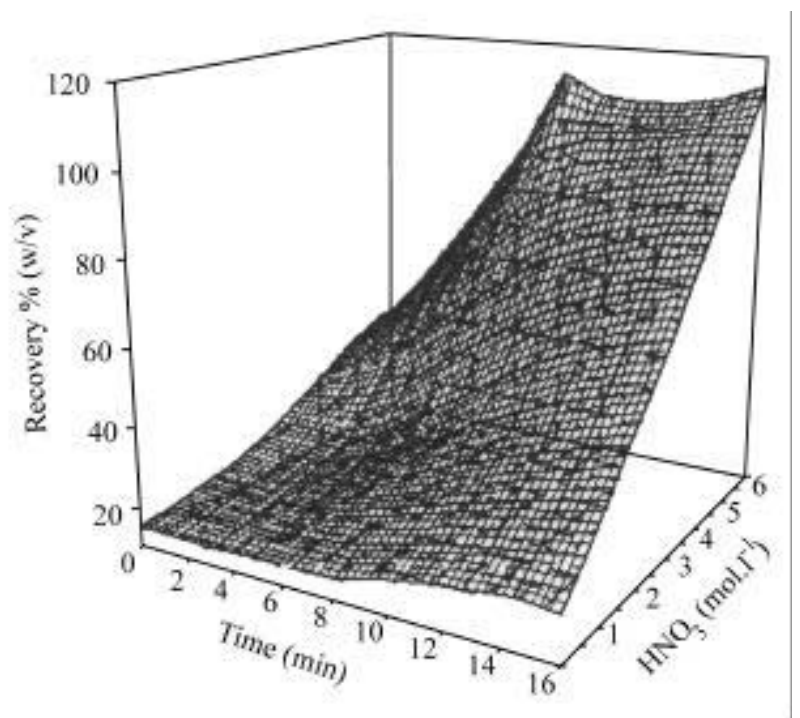

Figure 4. Response surface of the digestion conditions for lead recoveries in MA-A-2 Reference Material $n^{\circ}$ 1062/TM Fish Homogenate at variable digestion times and acid concentrations.

ditions in Fig. 1 and the furnace program shown in Table 2. The detection limit of $0.72 \mu \mathrm{g} \mathrm{L}^{-1} \mathrm{~Pb}$, and the characteristic mass of $29.8 \mathrm{pg} 0.0044 \mathrm{~s}^{-1}$, were calculated using a $10 \mu \mathrm{g}$ $\mathrm{L}^{-1} \mathrm{~Pb}$ standard solution according to IUPAC recommendation $^{36}$. Precision was estimated by analyzing fish samples (Sarrassalmus sp.). Repeatability of $10.5 \%(\mathrm{n}=20)$ and reproducibility of $14.3 \%(n=10)$ were calculated.

The effect of the concomitants was evaluated by analyzing the variations in the analytical responses of $10 \mu \mathrm{g} \mathrm{L}^{-1}$ standard solution in the absence and presence of some elements (Table 4). Measurements were made in triplicate, and the results showed that lead can be determined in a matrix of similar chemical composition. A maximum signal difference of $\pm 10 \%$ was attributed to the inherent uncertainties of the method.Fish analysis

The accuracy of the proposed method was evaluated by analyzing fish homogenate material (certified lead concentration, $0.58 \mu \mathrm{g} \mathrm{g}^{-1}$ ) and by comparing it with the wet digestion procedure ${ }^{37}$ of fish samples using nitric and perchloric acids. The average of five consecutive determinations on

Table 4. Tolerated levels of the concomitants in the determination of $10 \mu \mathrm{g}^{-1} \mathrm{~Pb}$.

\begin{tabular}{lc}
\hline Concentration of the species $\left(\mathrm{mg} \mathrm{L}^{-1}\right)$ & Signal difference $(\%)^{*}$ \\
\hline $2 \mathrm{Fe}^{3+}$ & -10.0 \\
$2 \mathrm{Zn}^{2+}$ & +7.0 \\
$0.09 \mathrm{Cu}^{2+}$ & +6.0 \\
$400 \mathrm{~K}^{+}$ & +9.0 \\
$300 \mathrm{Na}^{+}$ & -6.0 \\
$300 \mathrm{Cl}^{-}$ & +9.7 \\
\hline
\end{tabular}

* Percentage difference between the signals obtained in the presence and absence of the concomitant species. 
Table 5. Lead content in lyophilized samples as determined by nitric-perchloric (Wet) and microwave decomposition (MW).

\begin{tabular}{lccc}
\hline Popular names in Brazil & Scientific name & \multicolumn{2}{c}{ Concentration* $\left(\mu \mathrm{g} . \mathrm{g}^{-1}\right)$} \\
& & Wet & MW \\
\hline Piranha & Serrassalmus sp. & $0.30 \pm 0.03$ & $0.29 \pm 0.03$ \\
Pirarucu & Arapaima gigas & $0.21 \pm 0.02$ & $0.23 \pm 0.01$ \\
Cascudo & Pterigo phichthys sp. & $0.19 \pm 0.02$ & $0.18 \pm 0.02$ \\
Pescada branca & Urophycis sp. & $0.20 \pm 0.01$ & $0.23 \pm 0.01$ \\
Fish homogenate $* *$ & - & $0.54 \pm 0.01$ & $0.57 \pm 0.03$ \\
\hline
\end{tabular}

* Mean \pm standard deviation $(\mathrm{n}=5)$; ** IAEA MA-A-2 n 1062/TM Reference Material (certified value: $0.58 \pm 0.07 \mu \mathrm{g} \mathrm{g}^{-1}$ ).

individual test portions was $0.57 \pm 0.03 \mu \mathrm{g} \mathrm{g}^{-1}$. The results obtained by the proposed on-line microwave digestion system are summarized in Table 5. By applying the $t$-test, both sets of results were similar at a $95 \%$ confidence level, indicating the accuracy of the proposed on-line slurry digestion method.

\section{Conclusions}

The proposed on-line microwave decomposition allows rapid fish slurry pre-treatment, the total time involved for the sample preparation and analysis not exceeding 25 min. No problems associated with high pressure were observed by collecting the digested fish sample in a open autosampler cup. The proposed system can be applied to other samples of similar or less complex chemical composition.

\section{Acknowledgments}

The authors are grateful to the Conselho Nacional de Desenvolvimento Científico e Tecnológico (CNPq, Brasília, Brazil), to A.L.D. Comitre for her collaboration in the stages of this research, and to E.A.G. Zagatto for language improvement.

\section{References}

1. Mckenzie, H.A.; Smythe, L.E.; Quan ti ta tive trace analysis of biological materials: principles and trace amounts of some macroelements., Elsevier, Amsterdam, 1988.

2.Nuttall, K.L. Lab. Med. 1995, 26, 118.

3.Francek, M.A. Environ. Pollut. 1994, 84, 159.

4.Renner, R. Env. Scien. Technol. 1994, 29, 256 A.

5.Langmyhr, F.J.; Wibetoe, G. Prog. Anal. At. Spectrom. 1985, 8, 193.

6.Ebdon, L.; Lechotyck, A. Microchem. J. 1986, 34, 140.

7.Benzo, Z.A.; Velosa, M.; Ceccarelli, C.; de la Guardia, M.; Salvador, A. Fresenius' J. Anal. Chem. 1991, 339, 235.

8.Arruda, M.A.Z.; Gallego, M.; Valcárcel, M. Anal. Chem. 1993, 65, 3331.
9.Arruda, M.A.Z.; Gallego, M.; Valcárcel, M. J. Anal. At. Spectrom. 1995, 10, 55.

10.Burguera, M.; Burguera, J.L.; Alarcón, O.M. Anal. Chim. Acta 1986, 179, 351.

11.Haswell, S.J.; Barclay, D. Analyst 1992 , 117 , 117.

12.Carbonell, V.; Morales-Rubio, A.; Salvador, A.;delaGuardia,M.;Burguera,J.L.;Burguera,M.J. Anal. At. Spectrom. 1992, 7, 1085.

13.Karanassios, V.; Li., F.H.; Liu, B.; Salin, E.D. J. Anal. At. Spectrom. 1991, 6, 457.

14.Gluodenis Jr, T. J.;Tyson, J.F. J. Anal. At. Spectrom. 1993, 8, 697.

15.Burguera, J.L.; Burguera, M. J. Anal. At. Spectrom. 1993, 8, 235.

16.Arruda, M.A.Z.; Gallego, M.; Valcárcel, M. J. Anal. At. Spectrom. 1995, 10, 501.

17. Madrid, Y.; Bonilla, M.; Cámara, C. Analyst 1990, 115, 563.

18.Viñas, P.; Campillo, N.; López Garcia, I.;

Hernández-Córdoba,M.FreseniusJ.Anal.Chem.1994, 349, 306.

19.Lynch, S.; Littlejohn, D. J. Anal. At. Spectrom. 1989, 4, 157.

20.Butcher, D.J.; Irwin, R.L.; Takahashi, J.; Su, G.;Wei,G.;Michel,R.G.Appl.Spectrosc.1990,44, 1521.

21.Stephen, S.C.; Ottaway, J.M.; Littlejohn, D. Fresenius' J. Anal. Chem. 1987, 328, 346.

22.Hoening, M.; Hoeyweghen, P.V. Anal. Chem. 1986, 58, 2614.

23.Madrid, Y.; Meseguer, J.; Bonilla, M.; Cámara, C. Anal. Chim. Acta. 1990, 237, 181.

24.Madrid, Y.; Bonilla, M.; Cámara, C. J. Anal. At. Spectrom. 1989, 4, 167.

25.Wagley, D.; Schmiedel, G.; Mainka, E.; Ache, H.J. At. Spectrosc. 1989, 10, 106.

26.Hernández-Córdoba, M.; López-García, I. Talanta 1991, 38, 1247.

27.Gervais, L.S.; Salin, E.D. J. Anal. At. Spectrom. 1991, 6, 41 . 
28.Mochizuki, T.; Sakashita, A.; Iwata, H.; Ishibashi, Y.; Gunji, N. Fresenius' J. Anal. Chem. 1991, 339, 889.

29.Stephen, S.C.; Littlejohn, D.; Ottaway, J.M. Analyst 1985, 110, 1147.

30.Bergamin, F.H.; Reis, B.F.; Jacintho, A.O.; Zagatto, E.A.G. Anal. Chim. Acta 1980, 117, 81.

31.de la Guardia, M.; Carbonell, V.; Morales-Rubio, A.; Salvador, A. Talanta 1993, 40, 1609.

32.Gilchrist, G.F.R.; Chackrabarti, C.L.; Cheng, J.; Hughes, D.M. J. Anal. At. Spectrom. 1993, 8, 623.
33. Fostier, A.H.; Ferreira, J.R.; Andrade, M.O. Quim. Nova 1995, 18, 425.

34.Kingston, H.M.; Jassic, L.B. In Introduction to Microwave Sample Introduction, ACS Professional Ref. Book, Washington, 1988.

35.Bergamin, F.H.; Zagatto, A.E.G.; Krug, F.J.; Reis, B.F. Anal. Chim. Acta 1978, 101, 17.

36.Analytical Methods Committee. Royal Society of Chemistry, Analyst 1987, 112, 189.

37.Tinggi, V.; Reilly, C.; Hahn, S.; Capra, M. J. Sci. Total Env. 1992, 125, 15.

FAPESP helped in meeting the publication costs of this article 